Utah State University

DigitalCommons@USU

$5-1954$

\title{
Age and Growth of the Utah Chub, Gila atraria (Girard), in Panguitch Lake and Navajo Lake, Utah, From Scales and Opercular Bones
}

John M. Neuhold

Utah State University

Follow this and additional works at: https://digitalcommons.usu.edu/etd

Part of the Aquaculture and Fisheries Commons

\section{Recommended Citation}

Neuhold, John M., "Age and Growth of the Utah Chub, Gila atraria (Girard), in Panguitch Lake and Navajo Lake, Utah, From Scales and Opercular Bones" (1954). All Graduate Theses and Dissertations. 3769.

https://digitalcommons.usu.edu/etd/3769

This Thesis is brought to you for free and open access by the Graduate Studies at DigitalCommons@USU. It has been accepted for inclusion in All Graduate Theses and Dissertations by an authorized administrator of DigitalCommons@USU. For more information, please contact digitalcommons@usu.edu.

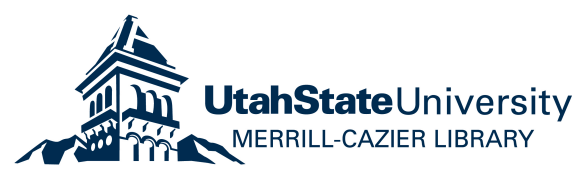




\section{AGE AND GROWTH OF THE UTAH CHUB, GILA ATRARIA (GIRARD), IN PANGUITCH LAKE AND NAVAJO LAKE, UTAH, PROM SCALES AND OPERCULAR BONES by John M. Neuhold}

A thesis submitted in partial fulfillment of the requirements for the degree

$$
\text { of }
$$

MASTER OF SCIENCE

In

F1shery Management 
378.2

\section{ABSTRACT}

Previous literature indicates the opercular bone as a. useful tool for the determination of age and growth of fish. The reliability and validity. of this method is tested for two populations of Utah chub. Age and growth are calculated for 222 Utah chub collected from Panguitch Lake and 212 Utah chub collected from Navajo Lake, southern Utah, in 1952-1953 from both scales and opercular bones. Scales are measured with the ald of a projector. Opercular bones are measured directly. The center of growth of the opercular bone is posterior to the posterior $11 \mathrm{p}$ of the fulcrum. Correction for curvature is necessary in opercular bone measurements. The body-scale relationships for both populations are linear. The body-opercular bone relationships for both populations are slightly curvilinear. Agreement of dominant age classes for successive years, agreement of empirical length-frequency modes of young fish with calculated length-frequency modes of lower age classes, agreement of ages as indicated by scales and opercular bones, agreement of age with sexually immature fish and an increase in length with an increase in age are accepted as evidence for both methods. Opercular bones have less variation for calculated lengths in older age classes while the scales have less variation in the younger age classes. The scale method is a generaliy more efficient method for determining the age and growth of the Utah chub. 


\section{ACKN OWLEDGEMENTS}

Sincere appreciation is expressed to $\mathrm{Dr}$. William $\mathrm{F}$. Sigler, Head of the Wildlife Management Department, Dr. Lew1s M. Turner, Dean of the School of Porestry, Dr. J. B. Low, Leader of the Utah Cooperative Wlldlife Research Un1t, Dr. Datus M. Hammond, Head of the Zoology Department, all of the Utah State Agricultural College, and Dr. Oliver B. Cope, Chlef, Rocky Mountain Fishery Investigations, U. S. Fish and Wildilfe Service, for their counseling and advisement in the presentation of this manuscript. Special thanks is due to Mrs. Ruth Neuhold whose assistance in the collection of data and the preparation of materlals for analys1s was indispensible, and to William J. Mcconnell, Project Leader in charge of Fishery Investigations for the Utah State Fish and Game Department, for his assistance In the collection of data and his advisement in the preparation of the manuscript. 
page

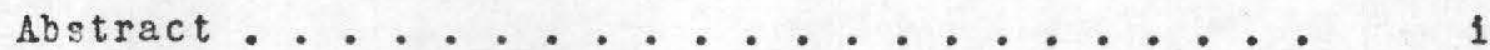

Acknowledgements ..................... 11

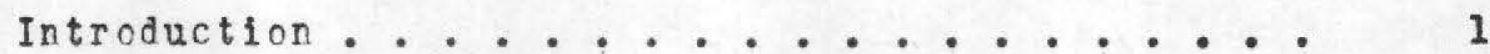

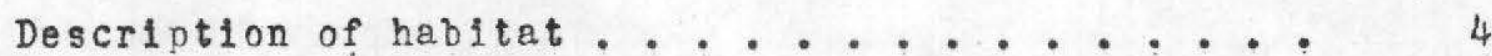

Methods used ........................ 8

Measurement and collection of data $: \cdots: 9$

$\begin{array}{ll}\text { Preparation of scales and opercular bones } & 10 \\ \text { for analysis } & \end{array}$

Reading and measuring : : : : : : : : 12

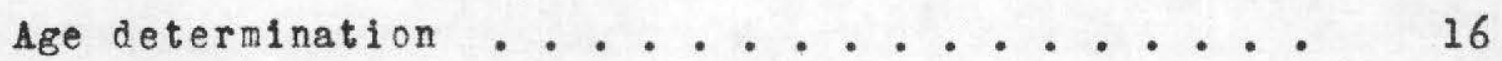

Calculation of past growth .............. 23

Correction of opercular bone measurements . . 23

Relationship of body to scales and oper-

Validity of annuli as year marks ....... 33

Accuracy of growth calculations ....... 40

Evaluation of the methods and conclusions .... 4 ?

Literature clted.......................... 49 


\section{INTRODUCTION}

Among the non-game $11 \mathrm{sh}$ that assume a role of $1 \mathrm{mpor-}$ tance in Utah is the Utah chub, Gila atraria (Girard). It assumes this role not because it is important economicaliy. It has little value as a food $\mathrm{fl} \mathrm{sh}$, nor is it used in any commerclal products. Recently, it has been used by fish hatchery people as a supplementary food material, but its utilization in this field is limited and has, as yet, reached no great proportions. It is of little value as a game P1sh. The sportsmen look upon the chub as a nulsance and seldom make attempts at catching them. Its real importance lies in the fact that the Utah chub reach large numbers in areas in which more desirable game flsh are present. Since the numbers of the chub are so large in some important trout fisherles, the competition for food and space with this more desirable species is suggested. Hazzard (1935) states that the Utah chub and trout are in direct competition for food in Fish Lake, Utah. Sigler (1948) states that trout and Utah chub stomachs contain much the same food.

The Utah chub inhabits a wide range in Utah. It has wide elevational and latitudional distribution and is found in every drainage of the state. It is predominantly at elerations between 5,000 and 9,000 feet. These lakes and 
streams are also considered to be good habitat for trout and are being maintained and developed as such. Cansequently when the Utah chub begin to outnumber the trout it would appear that cause for concern is justified. In the light of such developments a life history study of the Utah chub is imperative.

One of the most important phases of a life history study is that concerned with age and growth. It was with the age and growth of the Utah chub in mind that collection of data was initiated in June of 1952 at Panguitch Lake and Navajo Lake in southern Utah.

Many age and growth studies, in the past, have been based on the scale method. Although this method is wellestablished as valid it is lacking in efflciency of technique. McConnell (1952) uses the opercular bone for establishing the age and growth of carp, Gyprinus carpio Linnaeus. The methods and techniques he uses, particularly in the collection and preparation of opercular bones for analys 1s, show 1mprovement over the scale method. He also finds less variation in the body length-opercular bone relationship than in the body length-scale relationship. LeCren (1947) presents similar evidence for the opercular bones of perch, Perca fluviatilis Linnaeus.

If the opercular bones of the Utah chub are a valid and efflcient method for the determination of age and growth, the method would be a valuable addition to a phase of the management of that fish. Consequently, the purpose 
of this paper becomes two-fold: (1) the establishment of the age and growth of the Utah chub, and (2) an evaluation of the opercular bone method for the determination of age and growth of the Utah chub. 


\section{DESCRIPTION OF THE HABITAT}

Panguitch Lake is located in Garfield County, Utah 20 miles south-west of the town of Panguitch on the Dixie National Forest. It lies in a round valley at an elevation of 8,175 feet abore sea level bounded on all sides by mountains ranging to 9,000 feet above sea level. The lake, with tributaries, commands a watershed of 67 square miles and Is drained by Panguitch Creek, a segment of the Sevier River drainage. Panguitch Lake has a surface area of. 1,226 acres and a storage capac1ty of 18,580 acre-feet. Before construction of an 1rrigation dam at the head of Panguitch Creek, the lake had a surface area of 777 acres and a maximum depth of 15 feet. It is supplied by three streams: Ipson Creek from the west, Clear Creek from the south and Blue Springs Creek from the south-east. The formations surrounding Panguitch Lake are of sedimentary sandstone and limestone deposited during the Eocene (Fenneman 1931) (McKee 1931).

Surface water temperatures were recorded in 1951 as follows: 40 degrees Fahrenhelt in June, 56 degrees Fahrenhe1t in July, 60 degrees Fahrenhe1t in August, 56 degrees Fahrenhelt in September. Temperatures recorded in August showed a decrease of 1 degree Fahrenheit for 6 feet of depth. The pH of the water in August of 1952 was 8.6. Carbonates present were $84 \mathrm{ppm}$ and b1-carbonates were 
$15 \mathrm{ppm}$.

The dominant regetation of the watershed is p1nus ponderosa Laws. and Artemesia tridentata Nutt. The dominant plants of Pangultch Lake are all submergents and consist almost entirely of potomogeton pusillus L., Potomogeton pectinatus L. and Myrlophyllum exalbescans Fernald. Varlous specles of game $11 \mathrm{sh}$ are present in the waters. All, however, are introduced. They include the cutthroat trout, Salmo gairdneri Gibbons; kokanee, oncorhynchus nerka (Suckley) and the eastern brook trout, Salvelinus fontinalis (Mitchill). The only non-game fish collected was the Utah chub, G1la atrar1a (G1rard). Jordan (1891) 11sts the mountain whitefish, Coregonus williamsoni Girard, as present, however, no whitefish appear in recent collections.

Narajo Lake is located in Kane County, 28 miles southeast of Cedar City, Utah also on the Dixle National Forest. It lies on the southern edge of the Markagunt Plateau at an elevation of 9,250 feet above sea level. The geology of the area is similar to that around Panguitch Lake. Navajo Lake presumably was formed by lava flows blocking the valley. The drainage is internal, apparently with exit through the porous lava. Water reappears 4 miles down the original valley in Duck Creek Springs. A dike has been constructed between the source of water and the drainage exit. Presumably, before construction of the dike, the basin was a dry lake. The source of the water supply 
exists in several subterranean springs along the north shore.

Navajo Lake drains a surface watershed of approximately 6 square miles. An additional watershed, created by recent volcanic activity and complicated by the same lava flows that formed Narajo Lake, also drains into Navajo Lake via sub-terranean springs. Surface area of the lake is 250 acres at dike level, and the lake has a storage capacity of 5,000 acre-feet. In June of 1952, the level of the lake was 6 feet above dike level with a maximum depth of the lake of 26 feet. In September of 1952, the level of the lake was still 2 feet above dike level. In September of 1953, the level of the lake was 3 feet below the level of the dike with a maximum depth of the lake of 17 feet.

Surface water temperatures were recorded in 1952 as follows: 46 degrees Fahrenheit in June, 58 degrees Fahrenheit in July, 65 degrees Fahrenheit in August, 59 degrees Fahrenhe1t. 1n September. The pH of the water in August of 1952 was 9.6. Carbonate content was 42 ppm, bi-carbonate content was $0 \mathrm{ppm}$ and the hydroxide content was $10 \mathrm{ppm}$.

The dominant vegetation of the watershed is pinus ponderosa Laws., Ables lasiocarpa (Hook) Nutt., Plcea engelman1 (Parry) Engelm., and Populus tremulo1des Michx. The aquatic vegetation is submergent and includes Myriophullum exalbescans Fernald., Potomoget on richardsonius (Berm.) Rydb., Potomogeton pectinatus L. and Potomogeton pusilius L. 
7

Fishing is maintained by continuous stocking of trout which include the rainbow trout, Salmo gairdner1 Gibbons; eastern brook trout, Salvelinus fontinalis (Mitchill); cutthroat trout, Salmo clark (Girard). Kokanee, oncorhynchus nerka (Suckled) were present in the lake in 1951. Also present are the Utah chub, Gila atrar1a (GErard); the smallein red-side shiner, Richardsonins balteatus hydrophlox (Cope) and the Bonneville mountain sucker, Pantosteus platyrhynchus (cope). 


\section{METHODS USED}

Collections

A total of 222 Utah chub were collected from Pangultch Lake from June to september, 1952 and in August and September, 1953. Several methods of collection were employed In an effort to obtain an equitable distribution of length classes.

Shore areas were polsoned with a water suspension of rotonone to obtain the smallest fish. This method proved to be the most effective since the fish inhabited an area that abounded with emergent vegetation and in which a small selne was difficult to operate. A 30 foot minnow seine with one-e1ght inch, bar measure mesh was operated in waters not exceeding 3 feet in depth. This method was effective for collecting chub from 70 to $130 \mathrm{~mm}$ in standard length. An experimental gill net (mesh size three-quarter inch to 2 inch, bar measure) set in waters ranging from 10 to 30 feet in depth was sufficient to collect the remainder of the length classes.

The 212 chub collected from Navajo Lake were taken between June and September of 1952 and in September of 1953 in a manner similar to that in Panguitch Lake. The smaller range of chub not included in the experimental gill net were taken with a 30 foot minnow seine. The seine was operated effectively since no emergent vegetation existed 
and the small chub frequented shallow, sandy shore areas. The gill net sets were made in various areas of the lake, however, only those sets made in spring areas captured fish, Indicating a concentration of the population in these areas. The sets were made at depths ranging from 10 to 25 feet.

Measurement and collection of data

All fish except those less than $40 \mathrm{~mm}$ in standard length were processed for data 1mmediately after capture. The smaller f1sh were preserved in a 10 percent formalin solution and examined later. Total, fork and standard lengths, as described by Carlander (1950), were taken to the nearest millimeter from a standard measuring board. Welghts were taken to the nearest gram with a balance accurate to one-tenth of a gram. The sex and maturity were determined by examination of the gonads.

All the scales were taken from an area on the flsh below and just anterior to the dorsal fin and above the lateral line on the left side. The scales were removed with a pen-knife using an anterior-posterior stroke. They were placed on a plece of 2 inch by 3 inch absorbent note paper which was folded and inserted into a coin envelope containing all pertinent data. The opercular bones were stored with the scales to avold confusion.

The left opercular bone of each fish was taken by grasping the opercular assembly between the thumb and the fore-finger, lifting up and foreward and tearing down 
and back thus eliminating the pre- and sub-operculars. Th1s operation rarely did damage to the bone and was accomplished with a minimum of effort. In the few instances in which the left opercular bone showed damage the right opercular bone was substituted. Th1s procedure was considered safe with the evidence demonstrated by McConnell (1952) on the symmetry of carp opereular bones. Preparat1on of scales and opercular bones for analys 18 Both scales and opercular bones were allowed to dry before cleaning. The scales were placed, along with the note paper, in the compartments of a plastic egg carton. Small squares of paper were numbered corresponding to the serial numbers of the data envelopes and included in the compartments with the scales. Water, at room temperature (about 60 to 65 degrees Fahrenhe1t), was then introduced Into the compartments, and the scales were allowed to soak for a period of not less than 15 minutes. When hot water was used, the scales disintegrated. After soaking, the scales were cleaned with fine forceps and a teasing needle. Fxcess water was removed by blotting the scales with the fingers. The scales were not allowed to dry completely before placing in the mounting medium, since they had a strong tendancy to curl.

Several mounting media were tried including gum arabic, gelatin-glycerin, clear syrup, sodium sillcate and a histological mounting medium under the trade name of "Technicon". All, except sodium silicate, were rejected as having some 
undesirable features such as a low refractive index, excessive bubbles, and requiring excessive care in handing. Clear syrup was good, but only for temporary mounts. The sodium sllicate medium was prepared by mixing one part of glycerin with three parts of sodium sillcate. A drop, the size of a dime, was placed on a 1 inch by 3 Inch slide. The scales were inserted into the medium and a cover slip was placed on top. The slides were allowed to remain in a horizomtal position for a period of 24 hours, then flled in a conventional slide box. The opercular bones were also placed in egg carton compartments. Bolling water was poured over the bones which were allowed to soak for 10 minutes. A fine forceps was the most sultable tool for taking off skin and accessory bones. A soft, flannel cloth completed the cleaning. The bones were placed in small envelopes and filed opposite the corresponding, mounted scales in the slide box.

The scales, mounted in the sodium silicate-glycerin medlum were well-preserved at the end of one year, and no differences in measurements of the projected scale were discernable. The orlginal facility for projecting and reading remained unchanged. The opercular bones, when dried for a period of a year, showed a tendancy to curl. Measurements were taken from the same bones one year later. With applied corrections for the increased concavity no difference in measurement was discernable. 
Scales and opercular bones from the smallest length groups (under $40 \mathrm{~mm}$ ) were treated in a different fashion. A segment of the skin was taken from the corresponding area from which scales were removed on the larger fish. The skin was mounted in sodium silicate-glycerin medium, and the scales were measured while still attached to the skin. The opercular assemblies were removed in their entirety and also mounted on slides. No attempt was made at clean1ng. The integument of the small fish was thin enough to be transparent. The outline of the opercular bones could easily be seen. Reading and measuring

The scales were read and measured with the ald of a micra-projector. Magnification used was $31.3 \mathrm{X}$. Best results were obtained by projecting the image on a dull surface. Surfaces painted with flat paint, faded yellow or belge in color, were excellent. Use of polarized light was attempted but no difference in the quality of projection was attained. The scales from an entire population were aged three times without reference to any preceding readings. When two successive readings agreed, the ages were accepted. Measurements were read directly from the projected image with a millimeter scale and recorded in age classes.

Various attempts at projecting the image of the opercular bones proved unsuccesful. LeCren (1947) projected the 1mages of perch opercular bones successfully with the ald of reflected and polarized light. This sys- 
tem was attempted, but the results were unsatisfactory in two respects: (1) the equipment used (an opaque projector) was impractical, both in size and operation, (2) the size of the projected image was too large, resulting in confuslon of annull when measurement was attempted. Transmitted light with magnification produced an image without clear annuli. The addition of polarized light did nothing to improve the image.

The system flnally adopted was that used by McConnell (1952) on carp opercular bones with modifications. The annull could easily be seen by placing the opercular bone on a black background using reflected light. Since the Utah chub opercular bones were considerably smaller than the carp opercular bones, callpers could not be used effectively in measurement. Instead, a white millimeter scale with,black calibrations was used agalnst a black backgr ound.

The opercular bone was placed with the center of growth directly over the "o" of the scale. The most posterlor margin was allgned over the calibrations, and measurements were taken on the straight line between the center of growth and the apex of the posterfor margin. The dorsal margin overlapped onto the black background, and the black calibrations of the rule extended across the line of measurement. The scale was read directly through the bone with the ald of a hand, magnifying glass (approximately two to three power) to the nearest one-half millimeter

\section{UTAH STATE AGRICULTURAL COLLEGE LIBRARY}


(Fig. 1). The mounted opercular bones were treated the same as the dry opercular bones. 


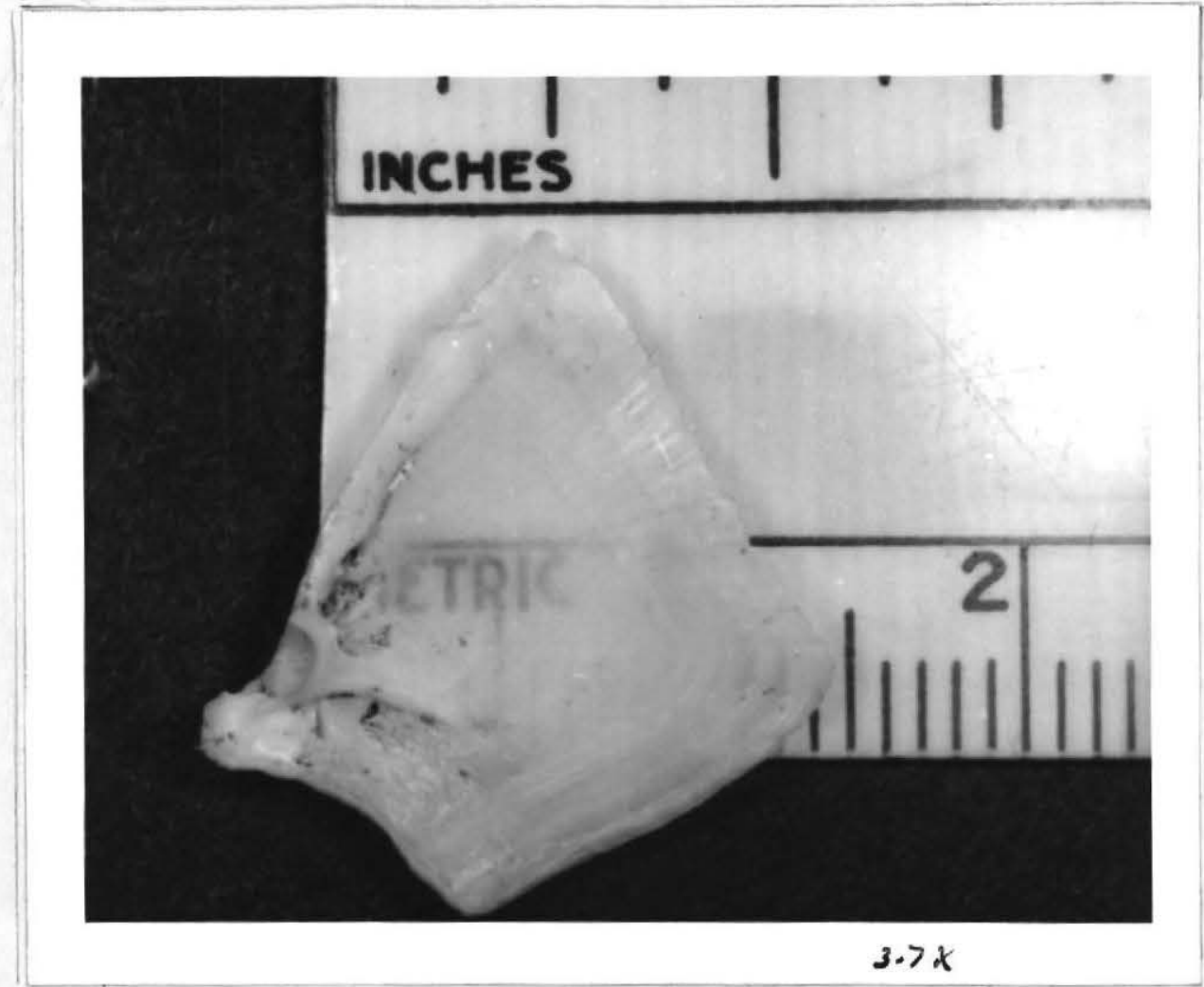

T1gure 1. Opercular bone in position for measurement. Hote the al1gnment of the center of growth with the apex of the posterior margin in relation to the millimeter scale. 


\section{AGE DETERMINATION}

The scales of the Utah chub are typically cycloid with pronounced shoulders on the lateral margins. Circull are clearly observed with a magnification of $31.3 \mathrm{X}$ and closely follow the outline of the scale. All annuli, except the first, are pronounced and include prominent check marks in the posterio-lateral field.

The first annulus appears close to the focus. The circuli of the winter growth of the fishes' first year of life appear, upon superficial examination, very much like the circuli of the preceding summer growth. However, a definite check mark appears in the lateral fleld for each first annulus. Empirical length-frequency histograms of zero-age fish captured late in the year shows the mode to be close to, yet less than, the mode of calculated length-frequencles for age class I (Fig. 2) (Fig. 3 ). Clark (1953) also finds an annulus close to the focus on scales of chub collected from Bear Lake, Idaho-Utah.

False annull appear quite frequently in the anterior fleld beyond the third annulus. However, no check marks appeared in any of the fields, and, consequently, they were eliminated. Examination of the scales of chub populations from Scofleld Reservolr, Carbon County, Gooseberry Reservo1r, San Pete County, Plute Reservo1r, Piute County, 


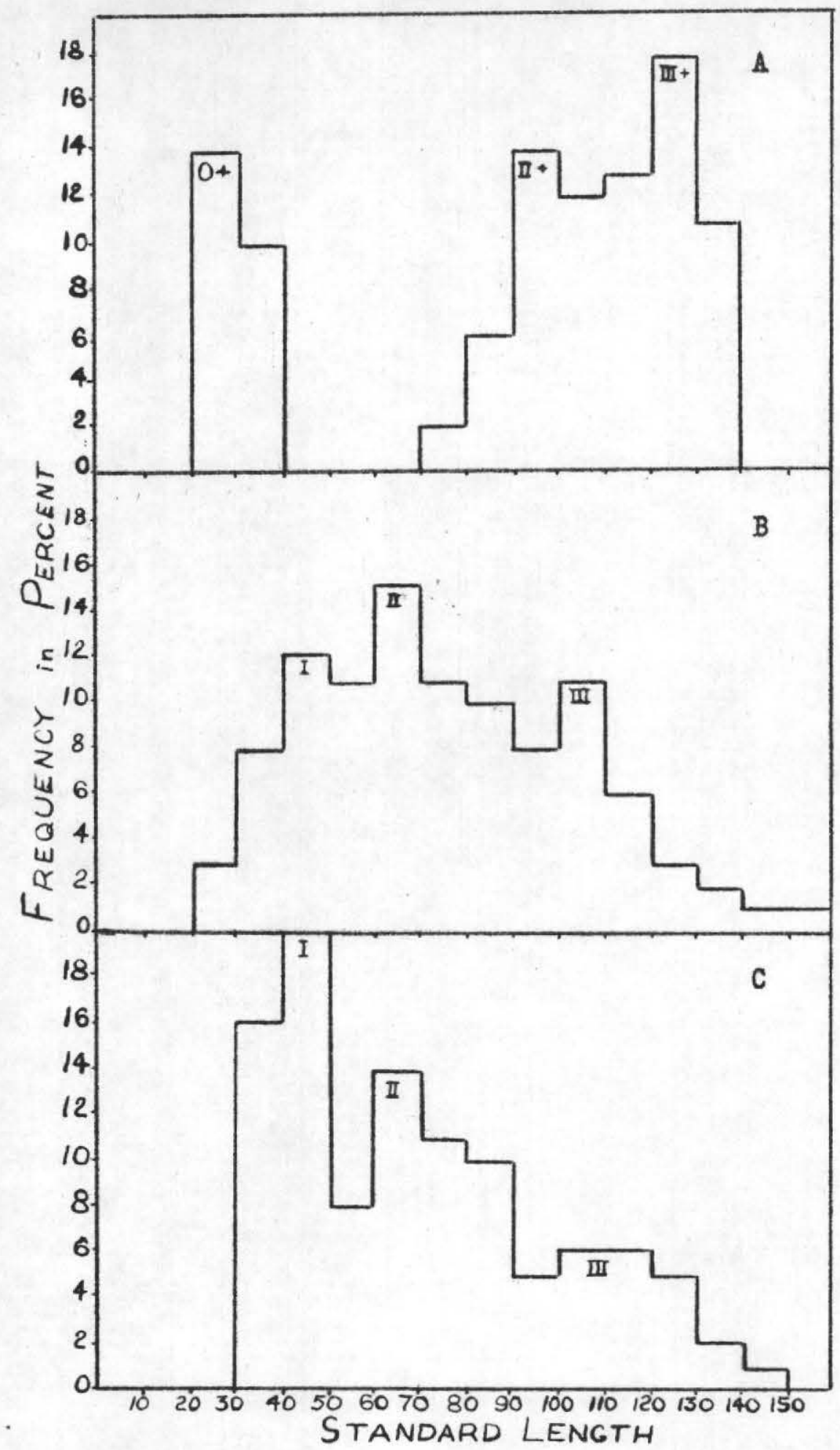

Figure 2. (A) Empirical length-frequencles of Utah chub collected from Navajo Lake in 1952.

(B) Frequencles of calculated lengths from the opercular bones of Utah chub collected from Navajo Lake in 1952 and 1953.

(c) Frequencles of calculated lengths from scales of otah chub collected from Navajo Lake in 1952 and 1953. The modes represent year classes. 


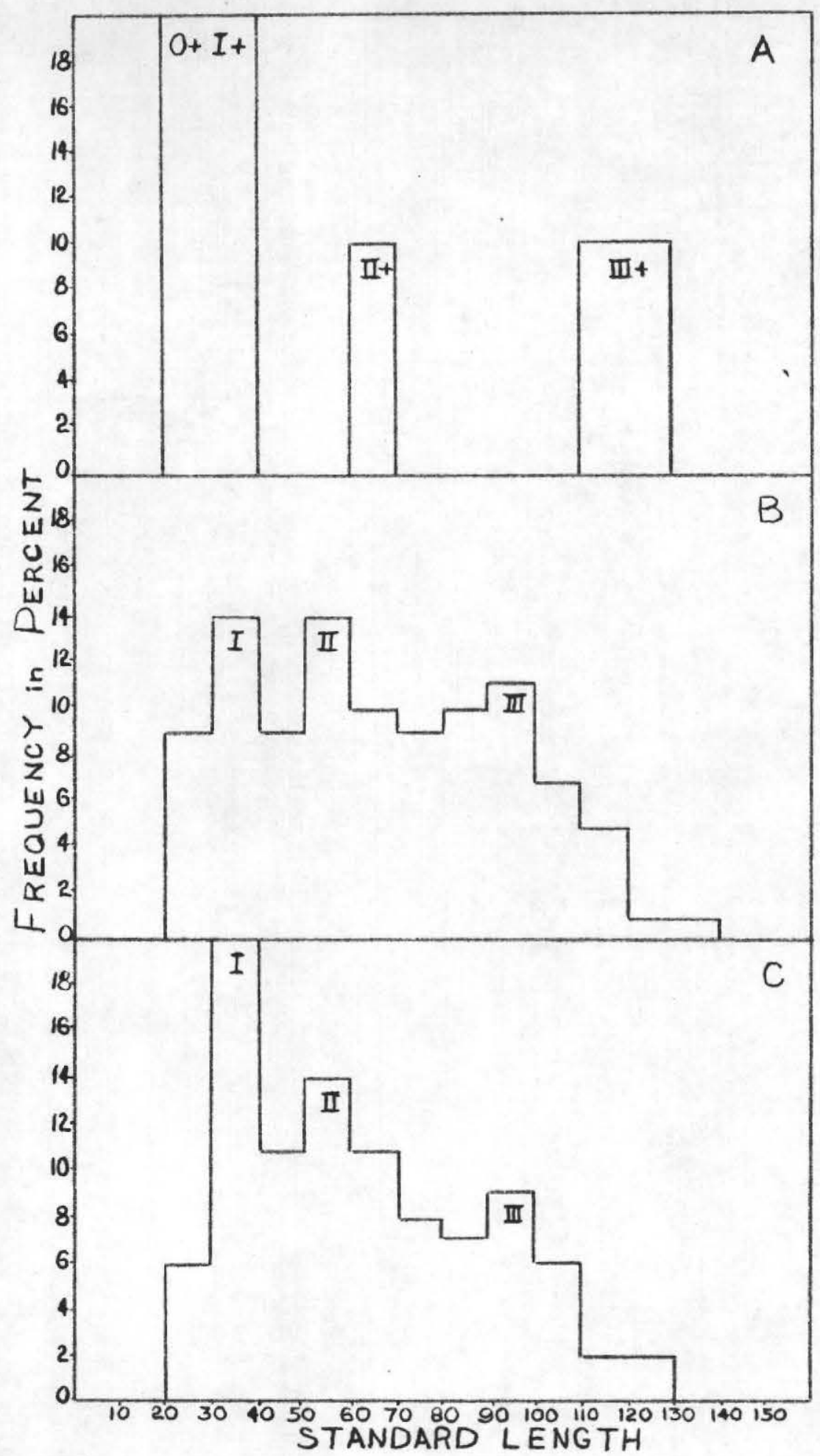

18 
Otter Creek Reservoir, Piute County and Koosharum Reservoir, Sevier County reveal descriptions similar to those mentioned.

The annuli of the opercular bones are represented by distinct, concentric bands and are essentially the same as those described by Lecren (1947) of perch opercular bones and by McConnell (1952) of carp opercular bones. Each band has two distinct elements: (1) a dark, narrow ring to the posterior, and (2) a transparent, wide band immediately anterior to the dark ring. It is assumed that the wide band represents the summer growth and the dark ring the winter growth. These bands are concentric In the outline of the opercular bone margin indicating that each dark ring represents the margin of the opercular bone at some time in the fishes' ilfe.

The flrst and second annuli are somewhat indistinct except on the line of measurement where they are placed with confidence. Many false annuli are present beyond the third year of growth. These false annuli, however, are easily identified. They are seldom as clear ss the true annuli and appear only in the posterior field of the opercular bone. Mcconnell (1952) finds similar conditions in the carp opercular bones.

Gross comparison of the annuli established on the opercular bones and the annuli established on the scales of the same flsh showed a remarkable similarity in relation to adjecent annuli (F1g. 4) (F1g. 5).

The ages established, howerer, differed in some of the 

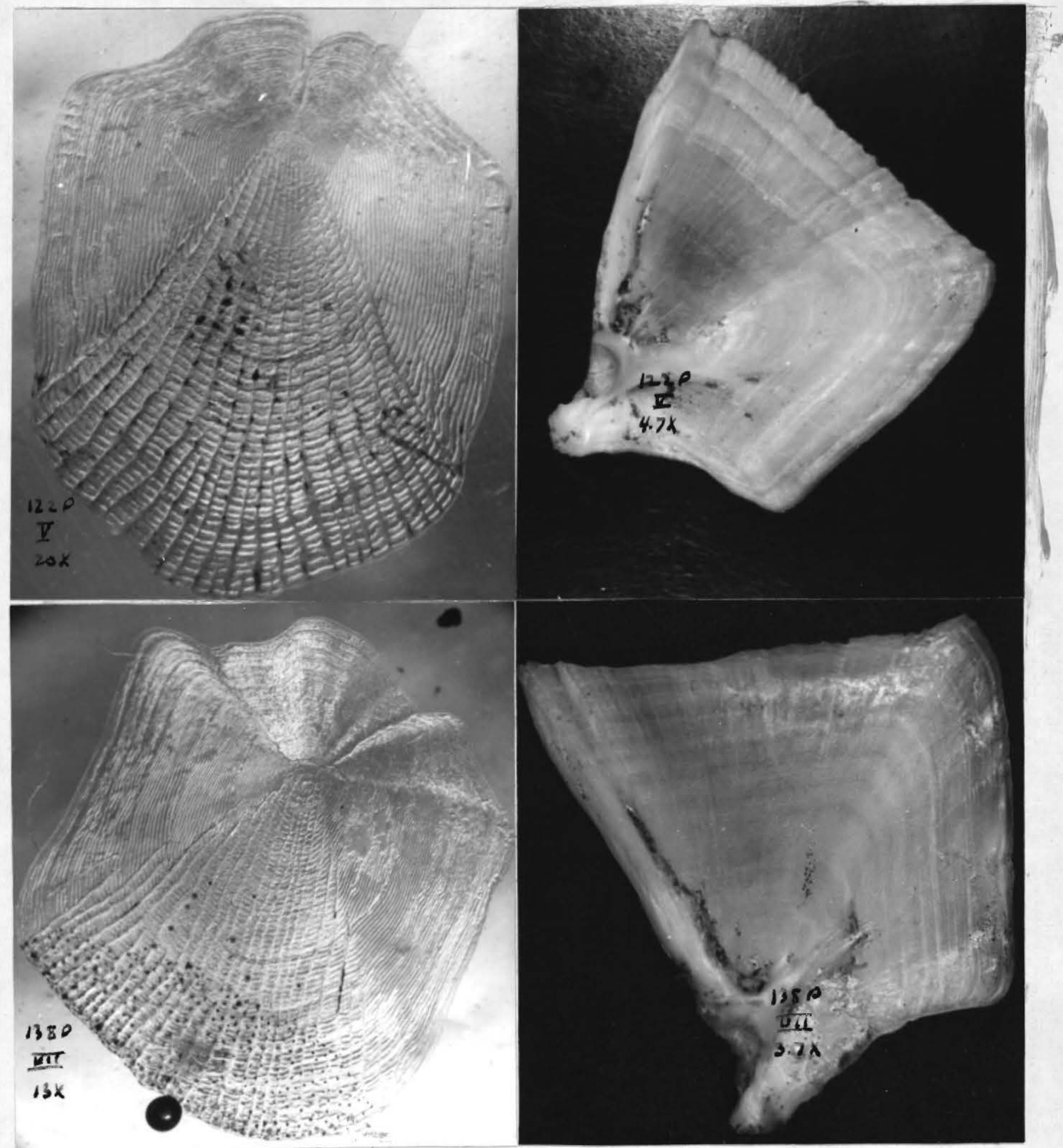

F1gure 4. Scales and opercular bones of fish collected from Panguitch Lake. Note the similarities of the annuli in relation to other annuli in both the scales and the opercular bones. 


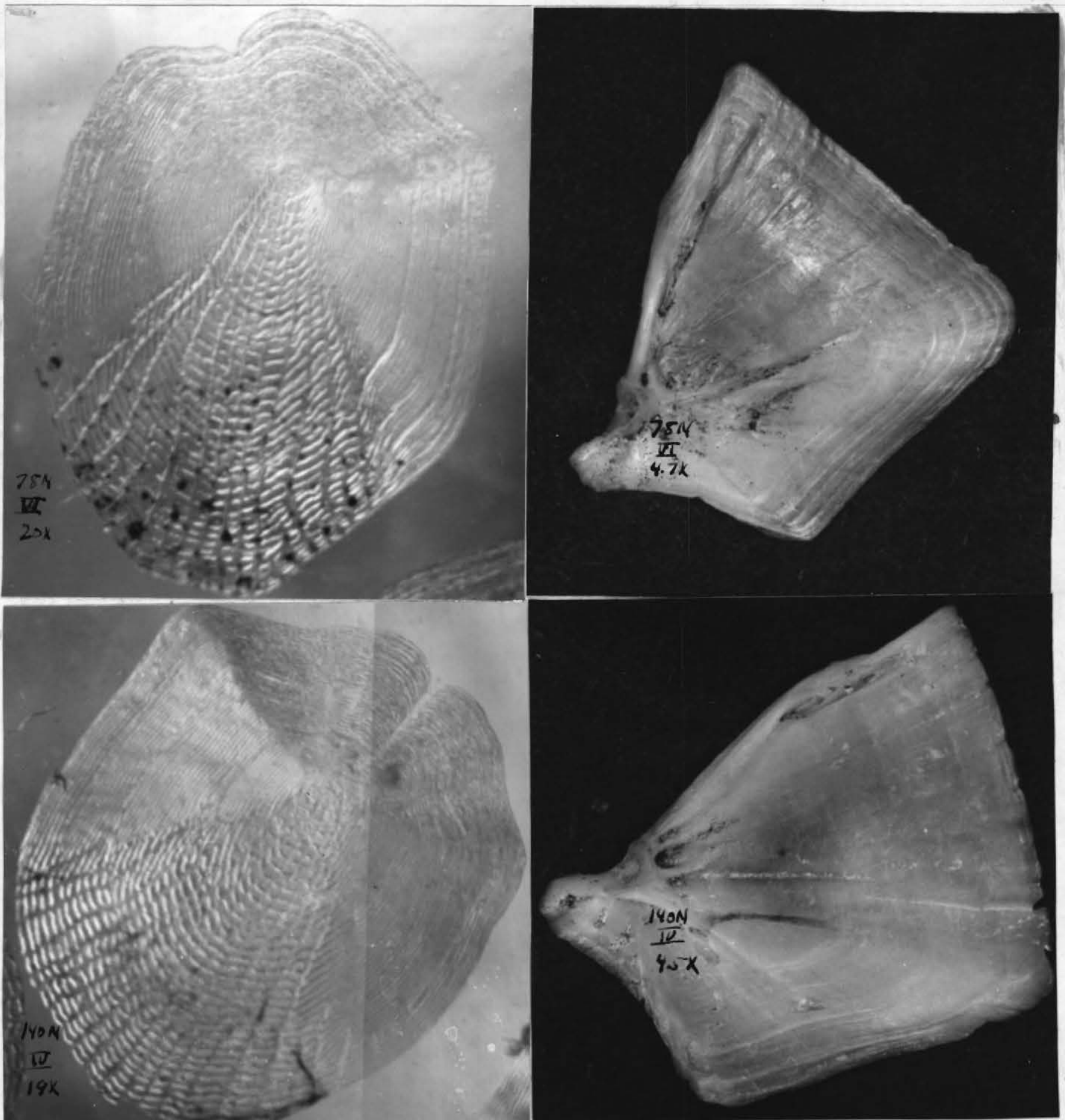

Figure 5. Scales and opercular bones of fish collected from Navajo Iake. Note the similarities of the annuli in relation to other annuli in both the scales and the opercular bones. 
f1sh. The Navajo Lake population differed in ageing of the opercular bone and the scale by 18 percent. Of the fish differing by the two methods, 91 percent differed by two years. Of the fish differing by one age class, 50 percent of the opercular bones had an age less than that shown by the scales.

The Panguitch Lake population differed in ageing by 13 percent, of which 83 percent differed by one age class, and 17 percent differed by two age classes. Fiftysix percent of the opercular bones differing by one age class showed an age less than that shown by the scales. Since the data collected included no known-age fish, no attempt was made at the reconcillation of differences of ages. Subsequentiy, those fish disagreeing in age were ommitted from the calculation of past growth, primarily for comparison reasons. 


\section{CALCULATION OF PAST GRONTH}

The assumption, for the calculation of past growth, that the length of the flsh must show a determinable mathematical relationshlp to the length of $1 \mathrm{ts}$ scales has become well-established. This assumption was demonstrated by Creaser (1926) and Van 0osten (1929) who also excellently summarize the work done to that time. More recent work on the theory of the scale method is summarized by Lagler (1950) and Hile (1941). Sigler (1953) presents excellent methods and procedure for the determination of the body-scale relationships.

The assumptions true for the calculation of past growth from scales are also true, with modifications, for the calculation of past growth from opercular bones. The prime assumption that the length of the $f 1 \mathrm{sh}$ and the length of the opercular bone can be expressed by a formula remalns unchanged; that the opercular bone lays down an annulus similar to the scale is rerifled by Lecren (1947) for the perch and by McConnell (1952) for the carp; that the opercular bones of a fish do not vary in number is not questioned.

Correction of opercular bone measurements

When measurement was inftiated the center of growth of the opercular bone was assumed to be directly beneath 
the posterior lip of the fulcrum, the point of articulation of the opercular bone. with the cranium. Lecren (1947) and McConnell (1952) measured from the posterior lip of the fulcrum of the perch and carp opercular bones respectively. This assumption is, however, false for the Utah chub. Growth of the fulcrum, instead of progressing perpendicular to the axis of the opercular bone, actually progresses along the axis, thereby removing the posterior $11 p$ of the fulcrum from the center of growth an added in crement for each year of life (Fig. 6).

Cross sections of 92 bonesfrom both populations were examined until the center of growth could be determined from surface examination. The opercular bones were then measured from the true center of growth.

A further correction necessary is the correction for curvature. In effect, the original measurements are recorded on the leg of a right triangle with the line from the point of curvature to the edge of the opercular bone as its hypotenuse and the helght to which the curve rises as its adjacent leg. The hypotenuse of this triangle is also the chord of an arc represented by the curvature of the opercular bone. These measurements represent an increment smaller than the true increment.

To adjust for this discrepancy, the opercular bone is placed convex side down on a flat surface. The height to which the opercular bone rises is measured and the point at which curvature begins is determined. The cur- 


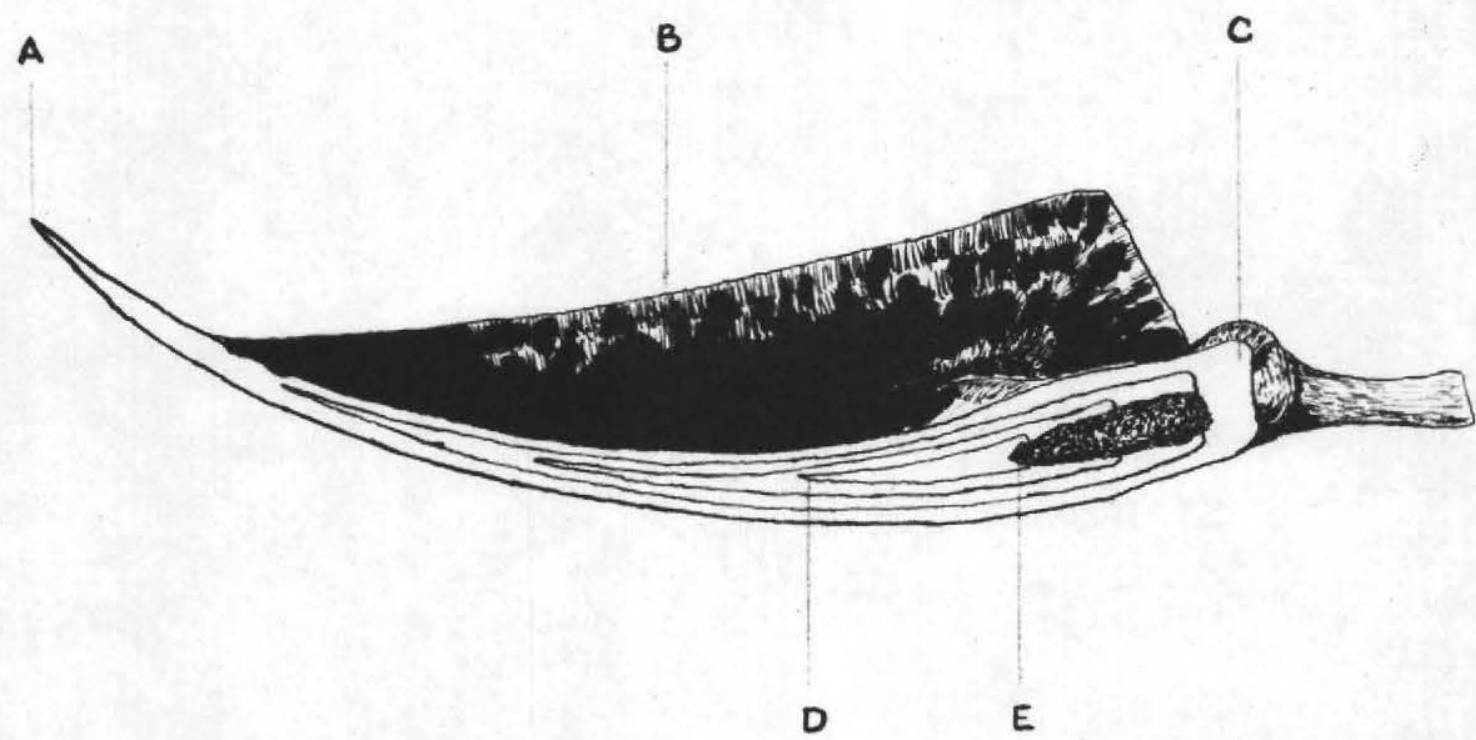

Figure 6. Opercular bone in diagramatic cross section:

(A) apex of the posterior edge, (B) Posteriordorsal edge, (C) posterior lip of the fulcrum, (D) first annulus and (E) true center of growth. The straight line between points $A$ and $C$ is the anterior-posterior axis of the opercular bone. 
vature is best described as parabolic and is fitted to the diagram by inspection. The annuli are placed on the curve and transposed to the leg of the triangle by dropplng perpendicular lines. Bach increment must be treated separately. Those increments affected by noticeable curvature were treated as segments of circles (a parabolic curve, when reduced to smaller, successive segments, can be treated as a series of circular arcs with increasing radi1 to a measurable $11 \mathrm{~m} 1 \mathrm{t}$ ), and the corrections are plotted from the radius through the annull to the line which contains the point of origin of curvature.

That segment of the parabola in which curvature is not measurable is treated as a straight line. Perpendiculars are extended from this line at each annulus to the line through the preceding annulus which exists at the same angle as the original angle. The increments of error are added to the original increments to the nearest onehalf unit (Fig. ?).

Corrections of measurement are considered necessary, since calculated lengths for uncorrected opercular bone measurements show a real difference from lenghts calculated from the corrected opercular bone measurements and also from the lengths calculated from scale measurements.

Relationships of body to scale and to opercular bone The body-scale $X 31.3$ relationship of 222 Utah chub from Panguitch Lake is best described by the formula,

$$
I=16.16+2.60 \mathrm{R} \text {, }
$$




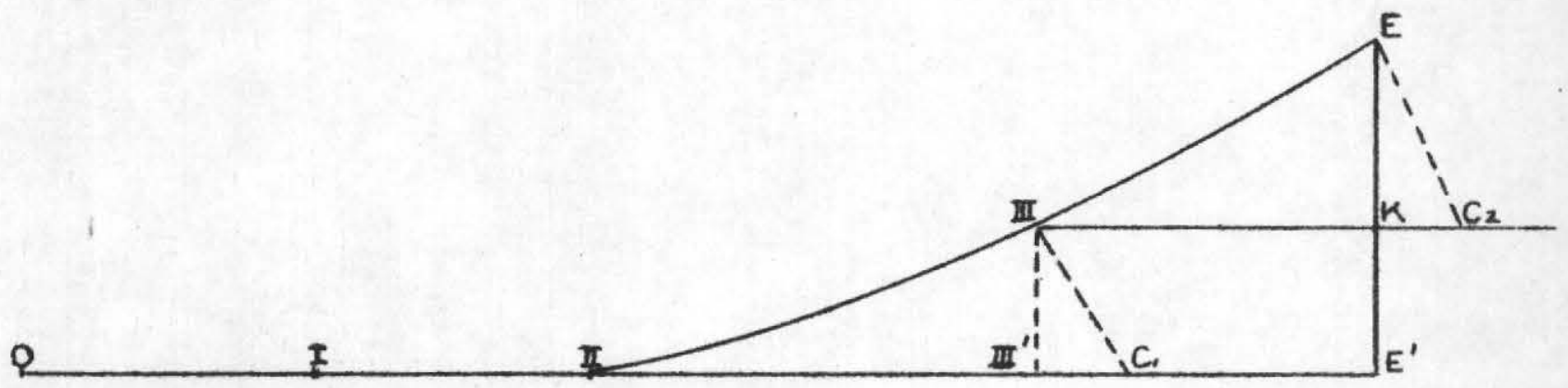

Flgure 7. A diagramatic representation of the correction for curvature of the opercular bone. The opercular bone is represented by points 0-I-II-III- s. III' and $\mathrm{BI}^{\prime}$ are the third annulus and the edge of the scale as recorded. Line III'C $C_{1}$ is the increment of correction at the third annulus determined by extending the radius, F-III-C 1 , of the circle of which arc, II-III, is a segment. $\mathrm{X}-\mathrm{C}_{2}$ is the increment of correction at the edge of the scale which is found by extending a perpendicular from line III-E at the edge of the scale. 


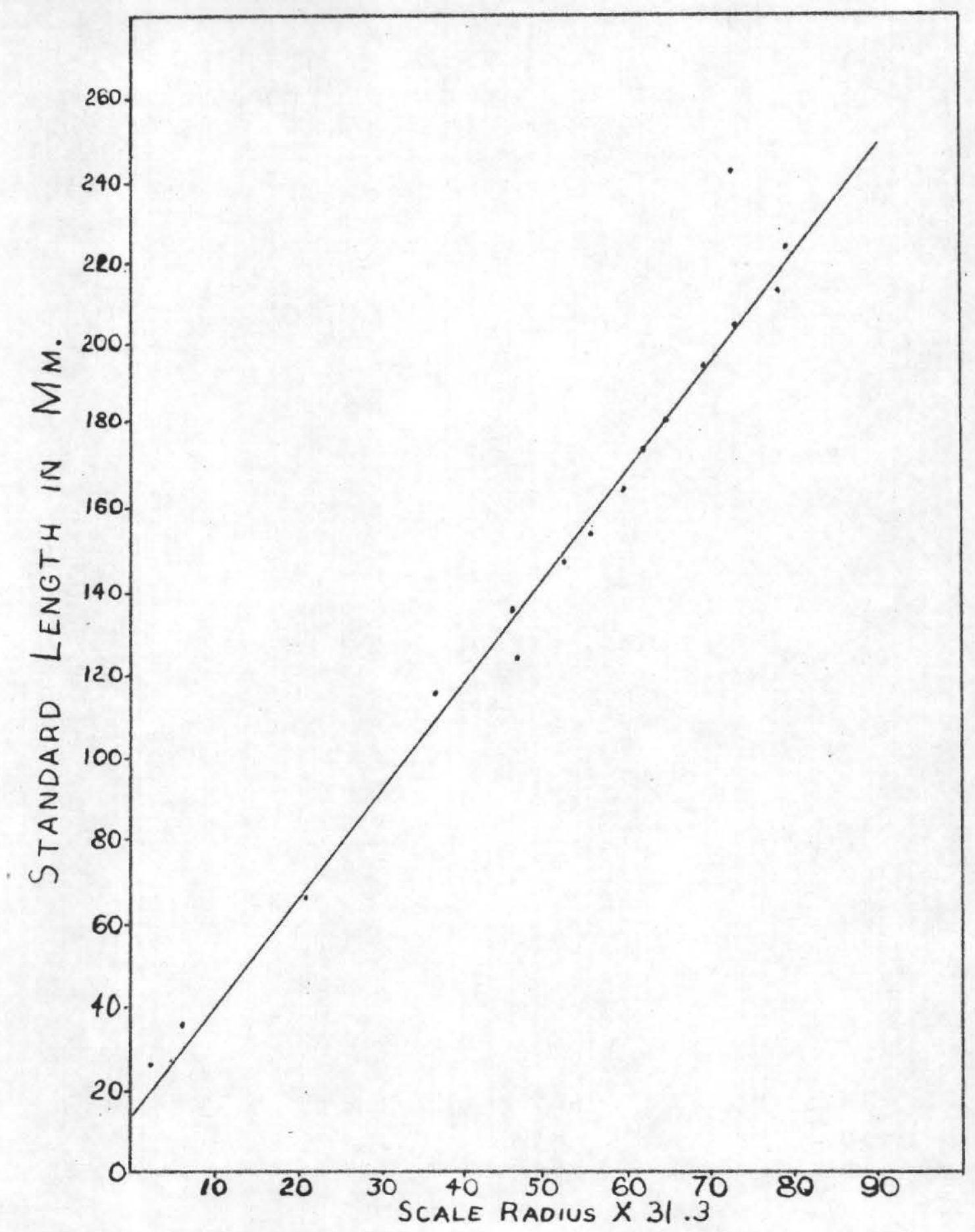

Figure 8. Relationship of the standard length to the posterio-lateral radius of the scale of Utah chub collected from Panguitch Lake, Utah. 


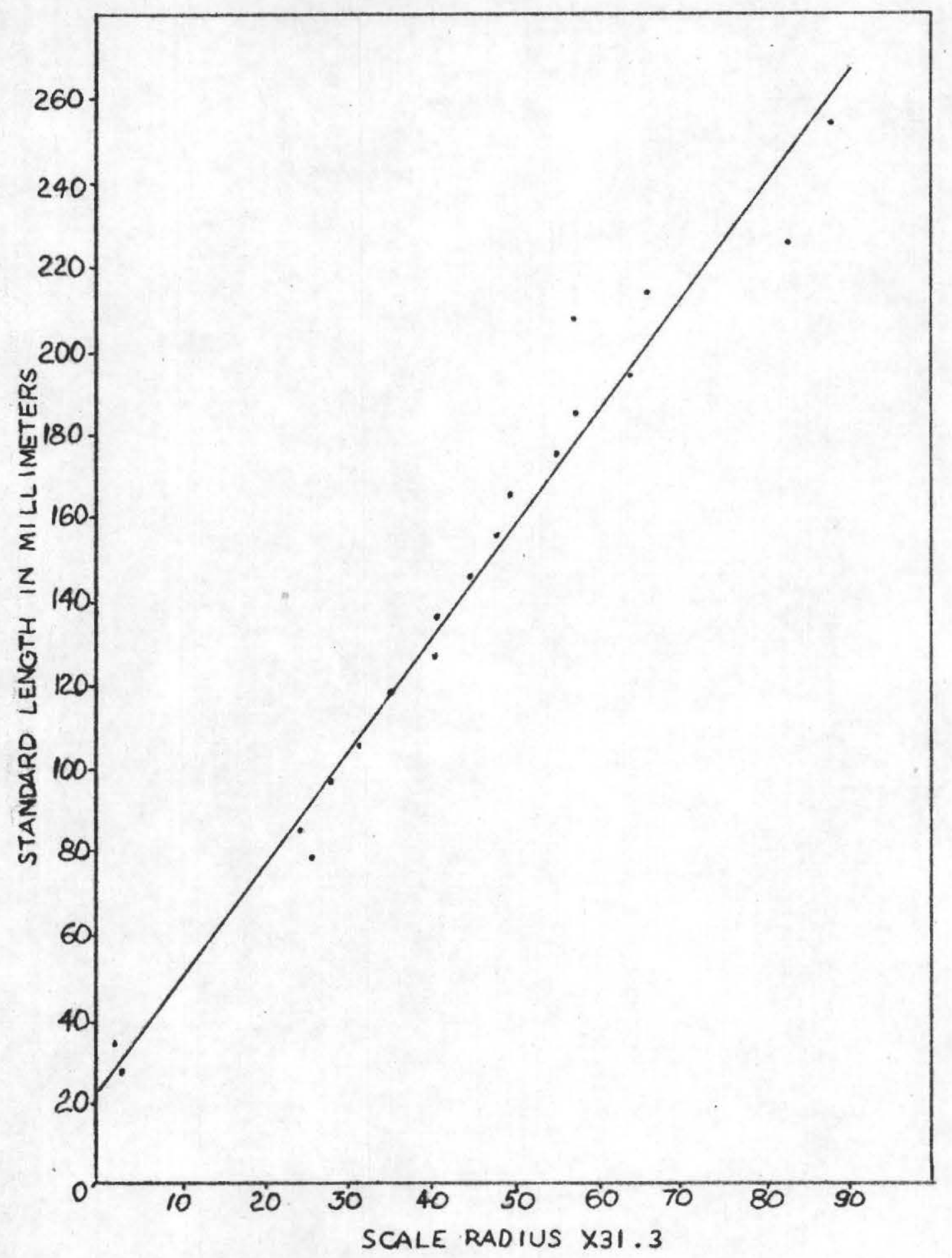

Figure 9. Relationship of the standard length to the posterio-lateral radius of the scale of Utah chub collected from Navajo Lake, Utah. 
where $L$ represents the standard length of the f1sh in millimeters at time of capture, and $R$ represents anteriolateral radius of the scale (Fig. 8). Similarly, the bodyscale $\times 31.3$ relationship of 212 Utah chub from Navajo Lake is best expressed by the formula,

$$
L=23.75+2.71 \mathrm{R} \text { (Fig. 9). }
$$

The body-opercular bone relationships are determined from the same numbers of flsh as the body-scale relationships. The formula used for the body-opercular bone relationships is the logarithmic, exponentlal formula used by Manastrysky (Lagler, 1950). McConnell (1952) uses Manastrysky's formula for carp opercular bones, and Lecren (1947) finds it best for the perch opercular bones. The body-opercular bone relationship of Utah chub from Panguitch Lake is best described by the formula,

$$
L=4.263 R^{1.070}
$$

(P1g. 10). The formula that best describes the bodyopercular bone relationship of Utah chub from Navajo Lake $1 \mathrm{~s}$

$$
\left.\mathrm{L}=4.953 \mathrm{R}^{1.037} \text { (Fig. } 11\right) \text {. }
$$

Past growth is calculated from a nomograph essentially the same as the one described by Hile (1950). Only those lengths are calculated for flsh that agree in age by both methods for reasons of fair comparison. 


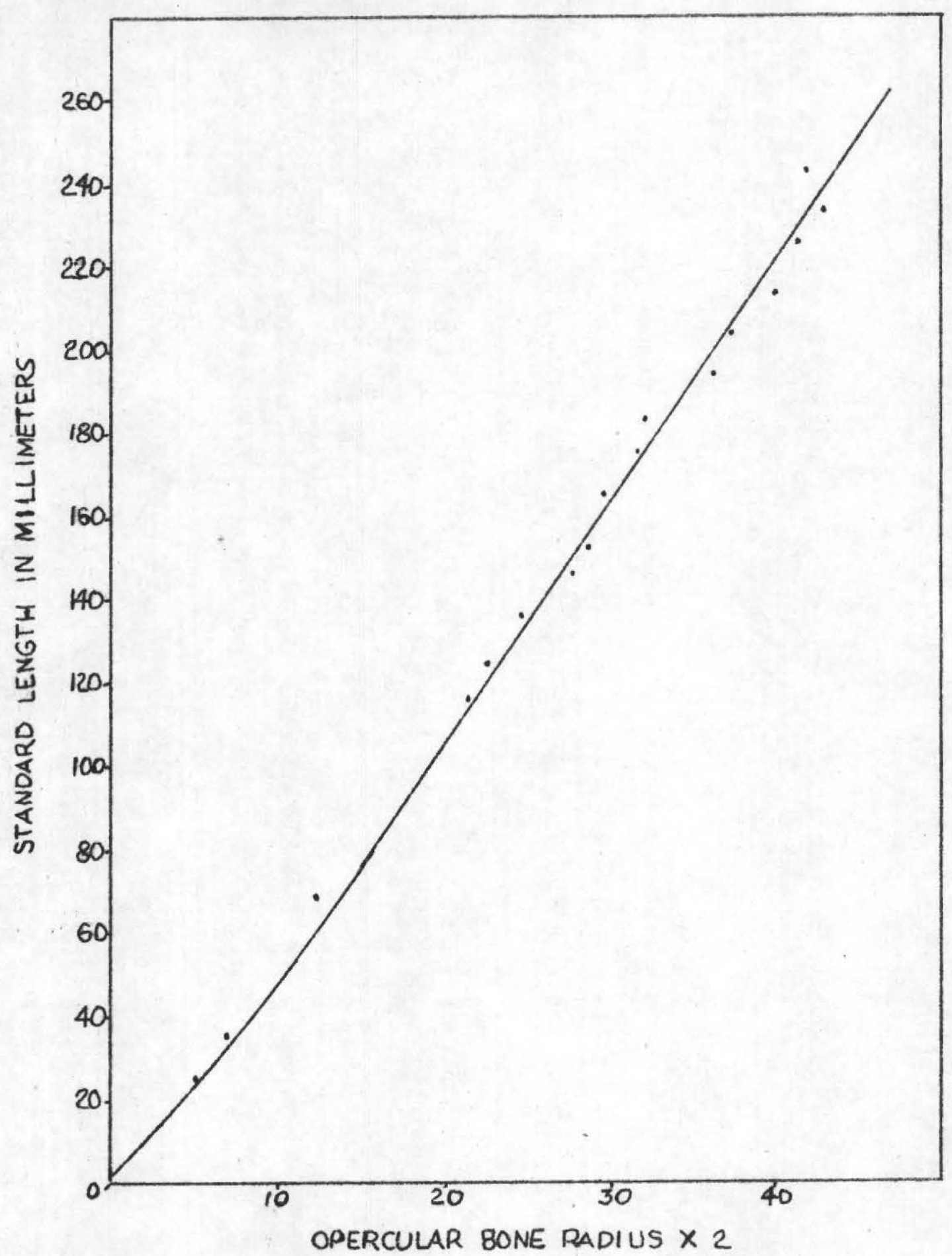

Figure 10. Relationshlp of the standard length to the posterlor radius of the opercular bone of Utah chub collected from Pangultch Lake, Utah. 


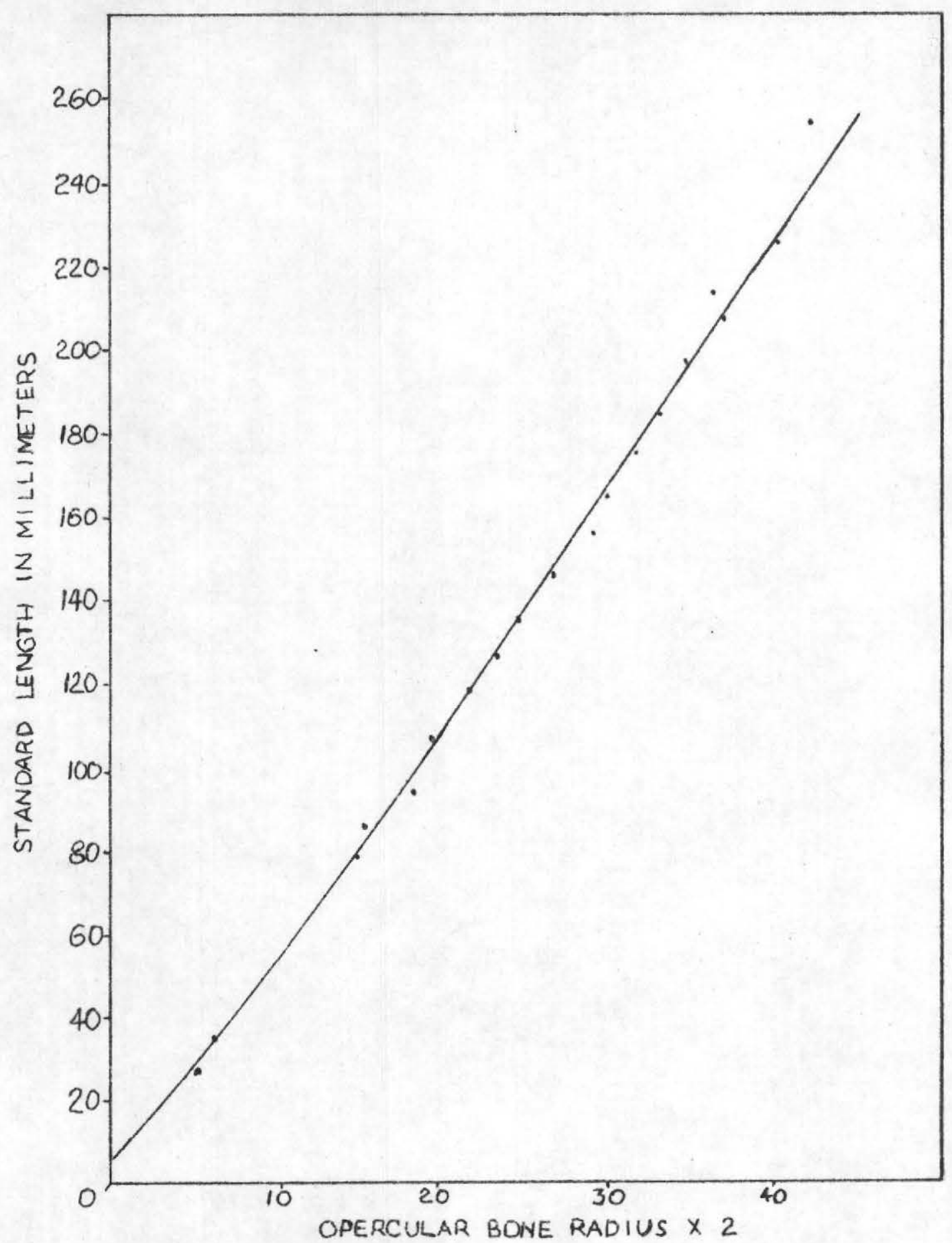

Figure 11. Relationship of the standard length to the posterior radius of the opercular bone of Utah chub collected from Navajo Lake, Utah. 


\section{VALIDITY OF ANNULI AS YEAR MARKS}

Establishing the validity of annull as year marks can be accomplished by several indirect methods. Van Oosten (1929) lists as several of the more important: (1) following the growth history of the edge of the scale to determine time of annulus formation, (2) establishing the dominant age class in the collections of at least two years, (3) known-age f1sh, (4) frequency modes of young fish should compare favorably with the length-frequency modes calculated from the annull and (5) the sexually Immature fish are the young fish. Hile (1941) lists essentialiy the same methods for establishing the validity of ages.

LeCren (1947) uses three of Van oosten's methods to establish the validity of the age of perch by the opercular bone: (1) growth history of opercular bones, (2) dominant age classes, and (3) frequency modes of young f1sh. McConnell (1952) uses as evidence for validity of age the number of annull of known-age carp opercular bones and the agreement of ages by opercular bones with ages by scales of the same fish.

The agreement of ages by opercular bones and scales is established in a previous section. That the agreement is close implies similarities in annulus formation on the opercular bone and the scale. 
Collections of opercular bones from $f 1 \mathrm{sh}$ of both populations were taken over a perlod of two years. Scales were collected from those same fish except for the Panguitch Lake population in which three years are covered. An opportunity is thus presented for a comparison of frequency peaks of age classes in successive years. Those fish that disagreed in ages by the two methods are allowed to remain in the frequency distributions in an effort to determine their distribution in the age classes. The numbers in each age class established by scales of fish collected from Panguitch Lake in 1951 show a peak for age class III. Th1s peak progresses to age class IV In 1952 and to age class $\nabla$ in 1953. Similarly, the general pattern of the histogram advances an age class for each successive year. Of the ages determined by opercular bones two peaks are apparent in 1952 for age classes IV and VII. Two peaks also appear in 1953 in age classes V and VIII (FIg. 12) (Fig. 13).

The Navajo Lake population presents a similar picture. For ages established from scales, the age class-frequency peak palls in age class III in 1952 and progresses to age class IV in 1953. The dominant age class of ages determined from the opercular bones also falls in age class. III for 1952 and age class IV for 1953 (Fig. 14) (Fig. 15). Examination of these histograms also indicate increased helght of peakg for ages determined from opercular bones over the peaks of ages determined from scales except 


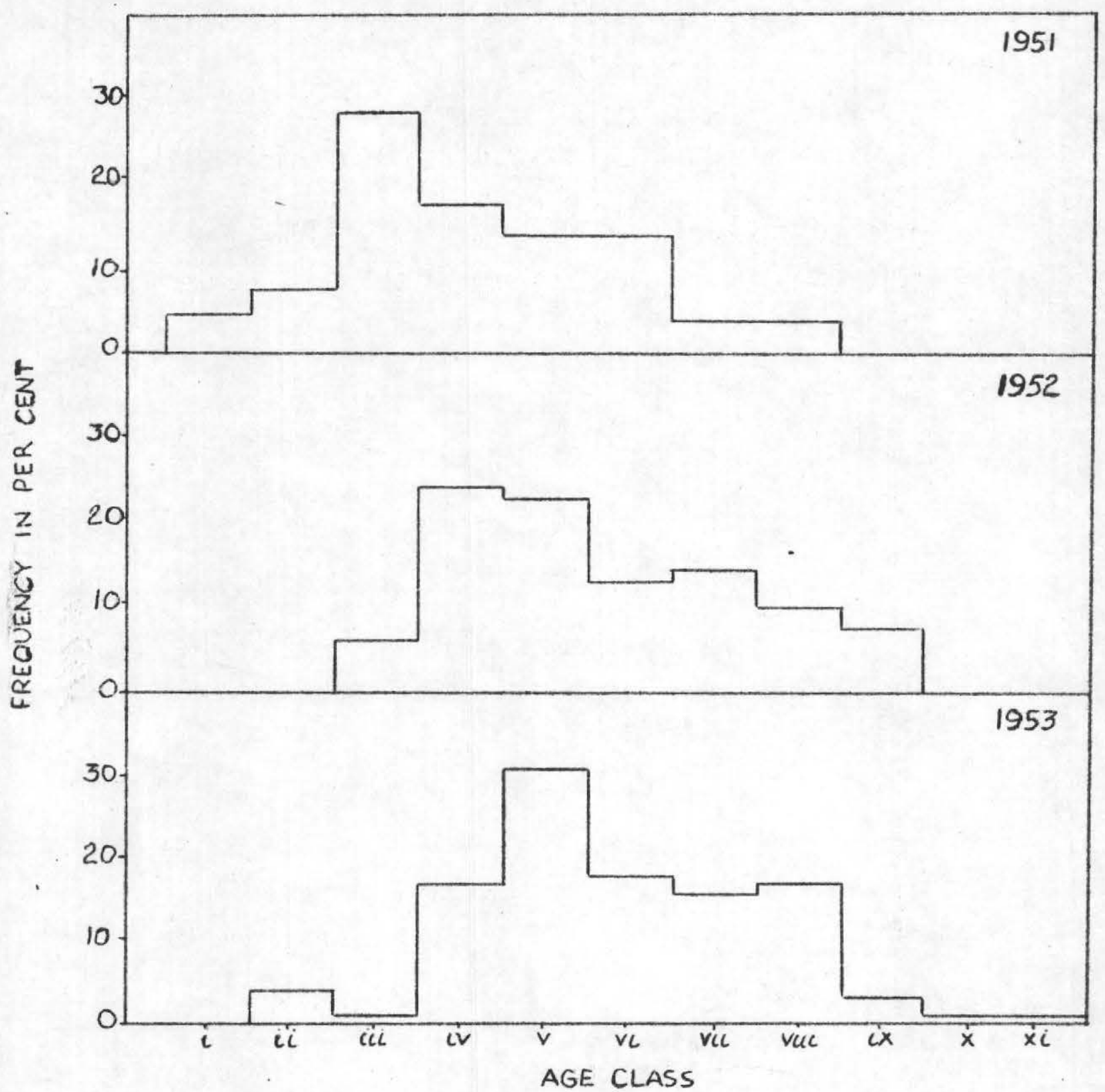

F1gure 12. Frequency distribution for Utah chub collected in 1951, 1952 and 1953 from Panguitch Lake by age class. The ages were determined from scales. The dominant age class is shown progressing in age class for each successive year. 


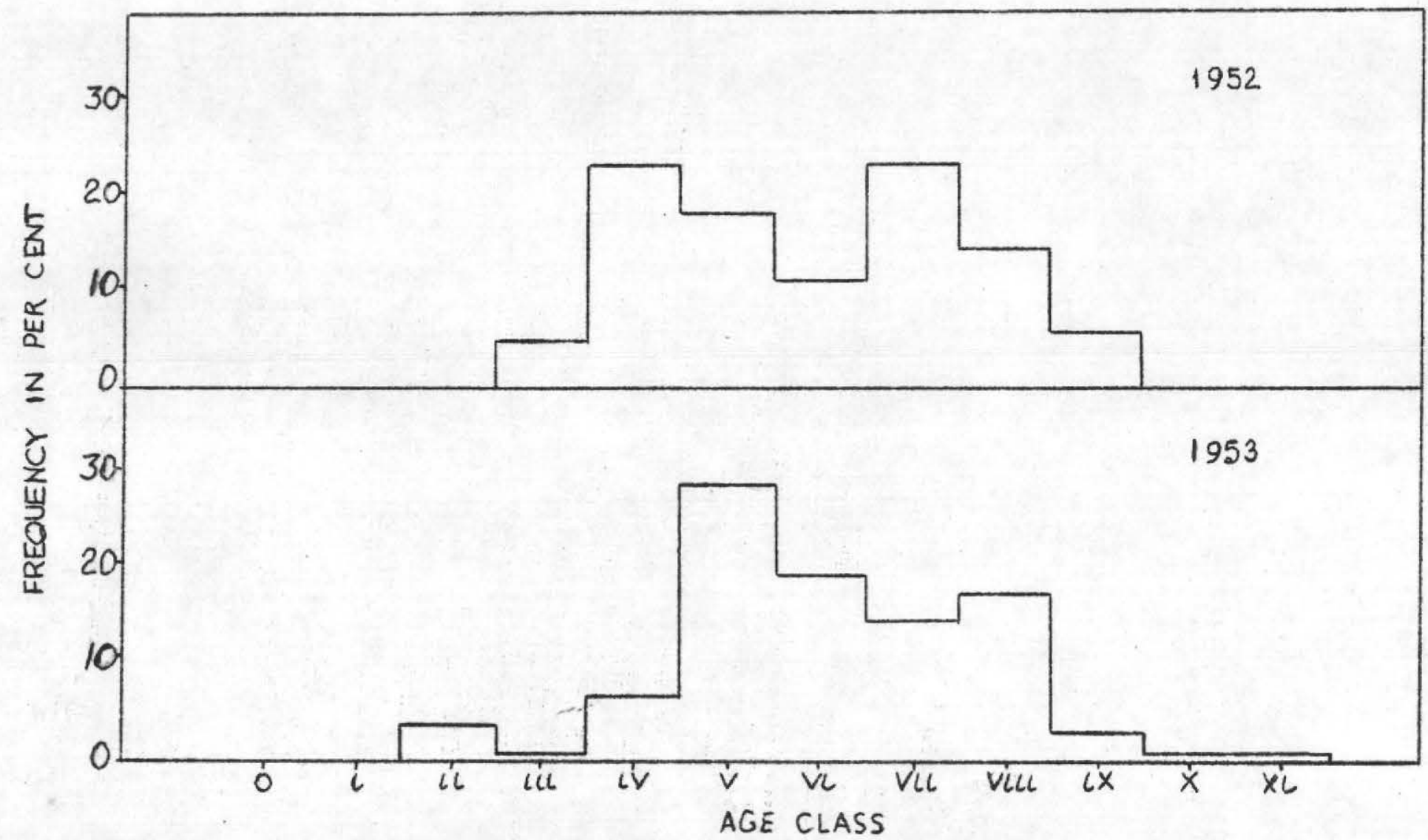

Figure 13. Frequency distribution for Utah chub collected in 1952 and 1953 from Panguitch Lake by age class. The ages were determined from opercular bones. 


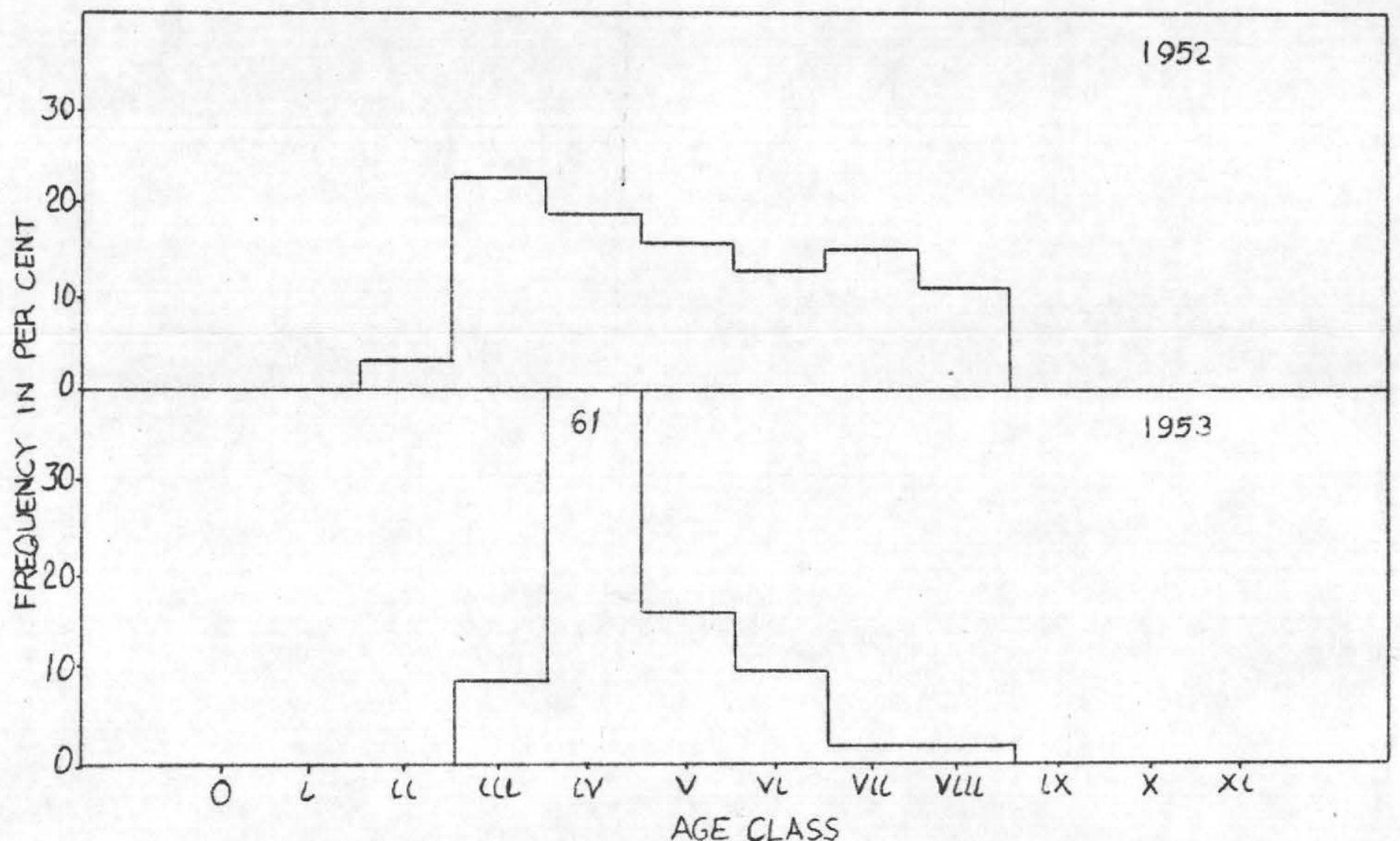

F1gure 14. Frequency distribution for Utah chub collected in 1952 and 1953 from Navajo Lake by age class. The ages were determined from scales. 


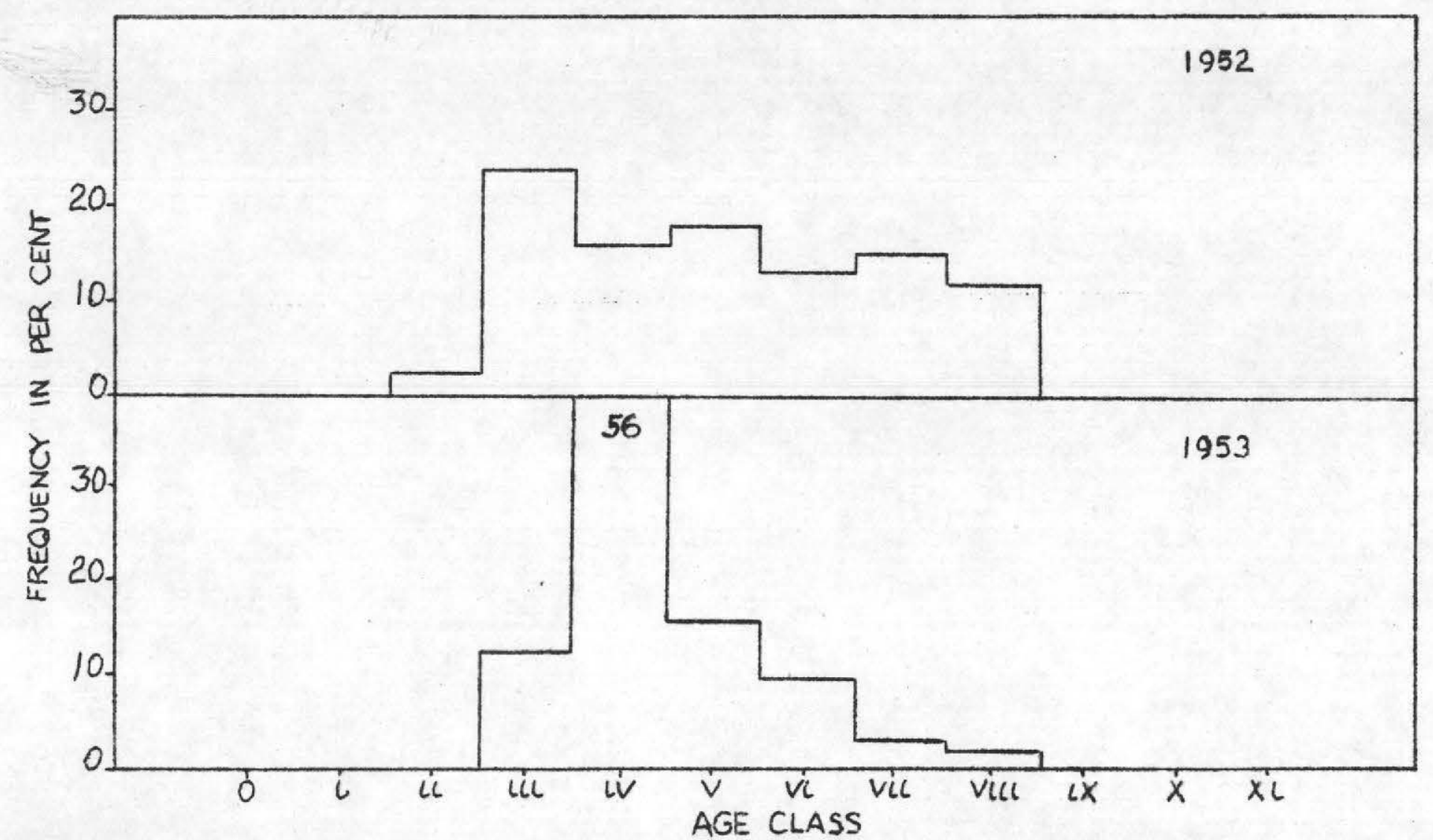

F1gure 14. Frequency distribution for Utah chub collected in 1952 and 1953 from Navajo Lake by age class. The ages were determined from opercular bones. 
for the peak of fish collected from Narajo Lake in 1953 where the reverse is true to a slight degree. The differences are not, however, predominant in any particular age class.

Close agreement of empirical length-frequency modes of small fișh with calculated length frequency modes is also apparent. Three modes are apparent in the Pangultch Lake population. The first mode is a composite of age classes 0 plus and I plus. The second and third modes represent age classes II plus and III plus respectively (PIg. 3 ). The Navajo Lake population sample lacks age class I. The empirical length-frequency mode for that segment of the population shows this nicely. The calculated length-frequency mode for age class I falls between the empirical length-frequency modes for age class 0 plus and age class II plus, indicating an absence of age class I plus from the empirical distributions (Fig. 2 ).

of the f1sh collected from Pangultch Lake that are sexually immature, 96 percent fall in age classes 0 and $I$. The remaining 4 percent are in age class II. In Navajo Lake, 83 percent of the sexually immature $f 1 \mathrm{sh}$ are in age class 0,10 percent in age class II and $?$ percent in age class III. All of the sexually fmmature in age classes II and III are males. 


\section{ACCURACY OF GROWTH CALCULATIONS}

The empirical length-frequency modes appear consistently in length groups slightly greater than the modes for the calculated length-frequencies. This relationship remains fairly constant for both methods and both populations, indicating close agreements. Further, the empirical length-frequency modes representing the 0 age class fall in a length group just slightly less than the calculated length modes for age class I. Since those fish of 0 age class were collected late in the growịg șeason, agreement 1 s st111 borne out (Fig. 2) (Fig. 3 ). The calculated length-frequency modes for the two methods also fall in the same length groups, indicating close relationship of the two methods. Bxamination of the length-frequency h1stograms for Navajo Lake and Panguitch Lake, however, reveal differences in the variance of calculated lengths between the two methods, The modes representing age class I by the scale method are high and pronounced. The successive modes representing age classes II and III grow progressively smaller and less pronounced, indicating an increase in variance of the calculated lengths w1th age.

The calculated length-frequency modes by the opercular bone method are comparatively level with little 
difference in height for successive modes and remaining at a level consistent with the mode for age class II by the scale method. This relationship appears to indicate a constant variance which, subsequently, means greater accuracy of growth calculations in older age classes.

The calculated lengths at the end of one year of life remaln consistent through the age classes with allowances for sample size. The absence in numbers of fish from age classes I, II, and III of the Panguitch Lake population is explainable by the increase of controlled poisoning of chub in 1950. The Navajo Lake population shows a complete absence of age class I. This is explainable partially by controlled chub polsoning in 1951 and also a heary freeze during the winter of 1951-1952 which may have increased mortality for the smaller fish frequenting the shallow, shore areas.

A close relationship also exists between the average standard length at time of capture and the average calculated length at the end of the last year of life in anyone age class. An exception appears in age class III for the Panguitch Lake population, probably due to the small size of the sample.for that age class (Table 1) (Table 2) (Table 3) (Table 4 ).

Agreement of the two methods for both lakes is close. The average lengths calculated from opercular bones are slightly higher than those calculated from the scales. The differences, though slight, may be explained by a blased inconsistency in the method. 
Table 1. Mean standard lengths and annual length increments in m1llimeters calculated from the scales of Jtah chub collected from Panguitch Lake in 1952 and 1953.

\begin{tabular}{|c|c|c|c|c|c|c|c|c|c|c|c|c|c|}
\hline \multirow[t]{2}{*}{$\begin{array}{l}\text { Age } \\
\text { Class }\end{array}$} & \multirow[t]{2}{*}{ Numbers } & \multirow{2}{*}{$\begin{array}{c}\text { Mean } \\
\text { Length } \\
\text { at Capture }\end{array}$} & \multirow[b]{2}{*}{1} & \multicolumn{2}{|r|}{ Mean } & \multicolumn{2}{|c|}{ calculated } & \multicolumn{2}{|c|}{ lengths } & \multicolumn{3}{|c|}{ at each annulus } & \multirow[b]{2}{*}{11} \\
\hline & & & & 2 & 3 & 4 & 5 & 6 & $\eta$ & 8 & 2 & 10 & \\
\hline $\begin{array}{r}I I \\
I I I \\
I I I \\
I V \\
V \\
\text { VI } \\
\text { VII } \\
\text { VIII } \\
\text { IX } \\
X \\
X I\end{array}$ & $\begin{array}{r}7 \\
5 \\
2 \\
25 \\
48 \\
30 \\
21 \\
27 \\
6 \\
2 \\
1\end{array}$ & $\begin{array}{r}52 \\
126 \\
127 \\
154 \\
172 \\
182 \\
194 \\
199 \\
207 \\
233 \\
230\end{array}$ & $\begin{array}{l}34 \\
40 \\
36 \\
34 \\
33 \\
35 \\
32 \\
35 \\
35 \\
39 \\
32\end{array}$ & $\begin{array}{l}90 \\
59 \\
59 \\
57 \\
58 \\
57 \\
59 \\
57 \\
56 \\
61\end{array}$ & $\begin{array}{l}93 \\
97 \\
93 \\
93 \\
92 \\
86 \\
84 \\
82 \\
85\end{array}$ & $\begin{array}{l}127 \\
130 \\
125 \\
120 \\
116 \\
119 \\
114 \\
127\end{array}$ & $\begin{array}{l}154 \\
148 \\
144 \\
137 \\
135 \\
138 \\
139\end{array}$ & $\begin{array}{l}165 \\
164 \\
155 \\
154 \\
159 \\
155\end{array}$ & $\begin{array}{l}179 \\
169 \\
171 \\
178 \\
166\end{array}$ & $\begin{array}{l}184 \\
187 \\
196 \\
184\end{array}$ & $\begin{array}{l}198 \\
212 \\
199\end{array}$ & $\begin{array}{l}223 \\
208\end{array}$ & 223 \\
\hline Total & 174 & & & & & & & & & & & & \\
\hline Grand & Averages & & 34 & 59 & 92 & 124 & 146 & 161 & 173 & 185 & 201 & 218 & 223 \\
\hline Annual & Increment & & 34 & 25 & 34 & 32 & 22 & 19 & 15 & 15 & 12 & 10 & 5 \\
\hline $\begin{array}{l}\text { Equive } \\
\text { Length }\end{array}$ & $\begin{array}{l}\text { lant Total } \\
\text { in Inches }\end{array}$ & & 1. & 2. & 4.4 & 46. & 6.9 & 7.7 & 8.3 & 38.9 & 99. & 610.5 & 10.7 \\
\hline Number & & & 174 & 167 & 162 & 160 & 135 & 87 & 57 & 36 & 9 & 3 & 1 \\
\hline
\end{tabular}


Table 2. Mean standard lengths and annual length 1ncrements in millimeters calculated from the opercular bones of Utah chub from Pangultch Lake in 1952 and 1953.

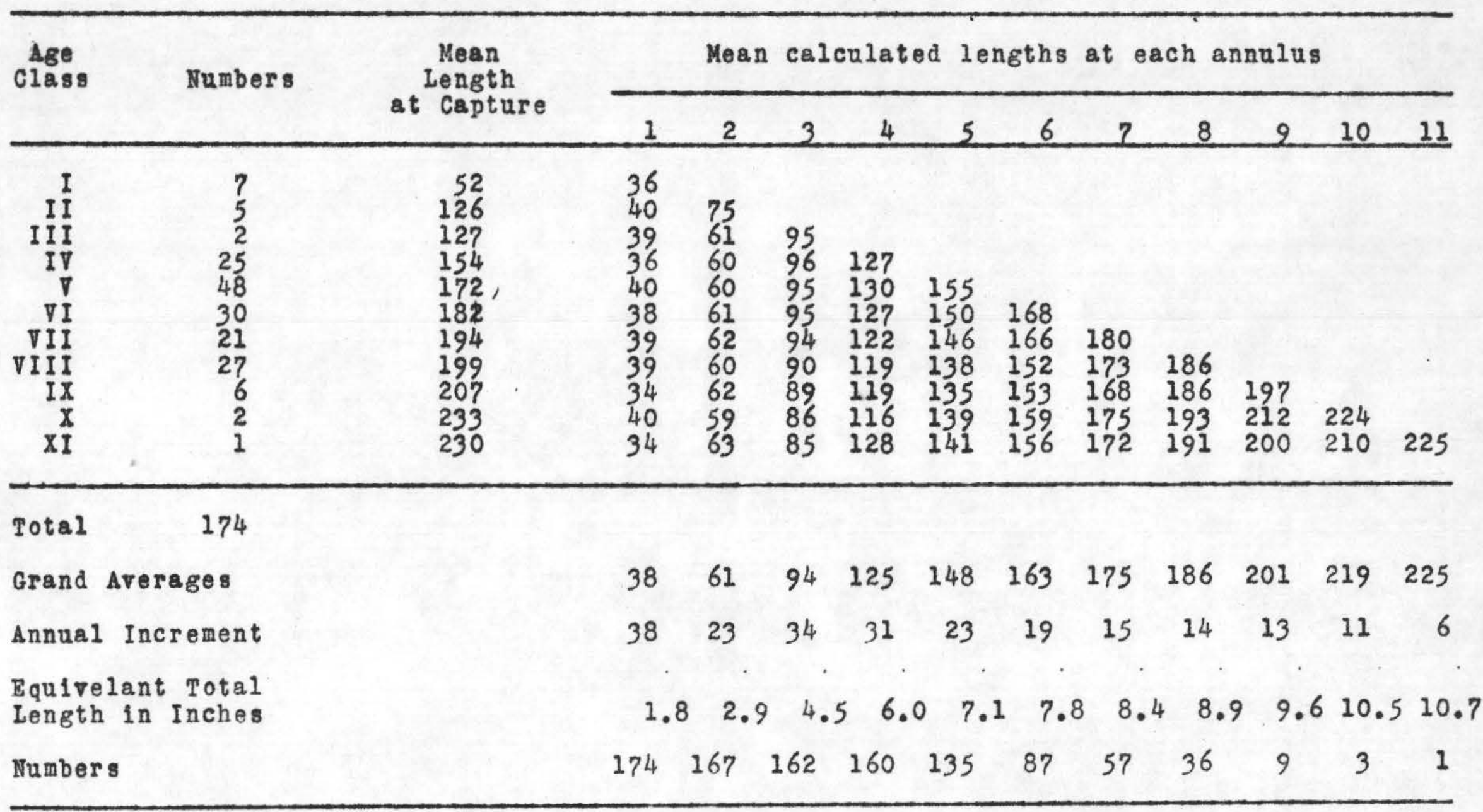


Table 3. Mean standard lengths and annual length increments in millimeters calculated from the scales of Utah chub collected from Navajo Lake in 1952 and 1953.

\begin{tabular}{|c|c|c|c|c|c|c|c|c|c|c|}
\hline \multirow{2}{*}{$\begin{array}{l}\text { Age } \\
\text { Class }\end{array}$} & \multirow{2}{*}{ Numbers } & \multirow{2}{*}{$\begin{array}{c}\text { Mean } \\
\text { Length } \\
\text { at Capture }\end{array}$} & \multicolumn{5}{|c|}{ Mean calculated lengths } & at each & \multicolumn{2}{|c|}{$h$ annulus } \\
\hline & & & 1 & 2 & 3 & 4 & 5 & 6 & 7 & 8 \\
\hline $\begin{array}{r}I I I \\
I I I \\
I V \\
V \\
V I I \\
V I I I \\
\nabla I I I\end{array}$ & $\begin{array}{r}36 \\
21 \\
59 \\
18 \\
11 \\
7 \\
3\end{array}$ & $\begin{array}{l}101 \\
130 \\
155 \\
169 \\
184 \\
190 \\
218\end{array}$ & $\begin{array}{l}39 \\
41 \\
41 \\
41 \\
41 \\
39 \\
44\end{array}$ & $\begin{array}{l}69 \\
70 \\
68 \\
66 \\
67 \\
64 \\
64\end{array}$ & $\begin{array}{r}110 \\
108 \\
105 \\
108 \\
103 \\
94\end{array}$ & $\begin{array}{l}139 \\
135 \\
137 \\
132 \\
127\end{array}$ & $\begin{array}{l}154 \\
156 \\
150 \\
154\end{array}$ & $\begin{array}{l}171 \\
165 \\
174\end{array}$ & $\begin{array}{l}177 \\
189\end{array}$ & 204 \\
\hline Total & 155 & & & & & & & & & \\
\hline \multicolumn{2}{|c|}{ Grand Averages } & & 40 & 67 & 107 & 137 & 154 & 169 & 181 & 204 \\
\hline \multicolumn{2}{|c|}{ Annual Increment } & & 40 & 27 & 39 & 30 & 20 & 15 & 13 & 15 \\
\hline \multicolumn{2}{|c|}{$\begin{array}{l}\text { Equivelant Total } \\
\text { Length in Inches }\end{array}$} & & 1.9 & 3.2 & 5.1 & 6.6 & 7.4 & 8.0 & 8.7 & 9.8 \\
\hline \multicolumn{2}{|c|}{ Numbers } & & 155 & 155 & 119 & 98 & 39 & 21 & 10 & 3 \\
\hline
\end{tabular}


Table 4. Mean standard lengths and annual length increments in millimeters calculated from the opercular bones of utah chub collected from Navajo Lake in 1952 and 1953.

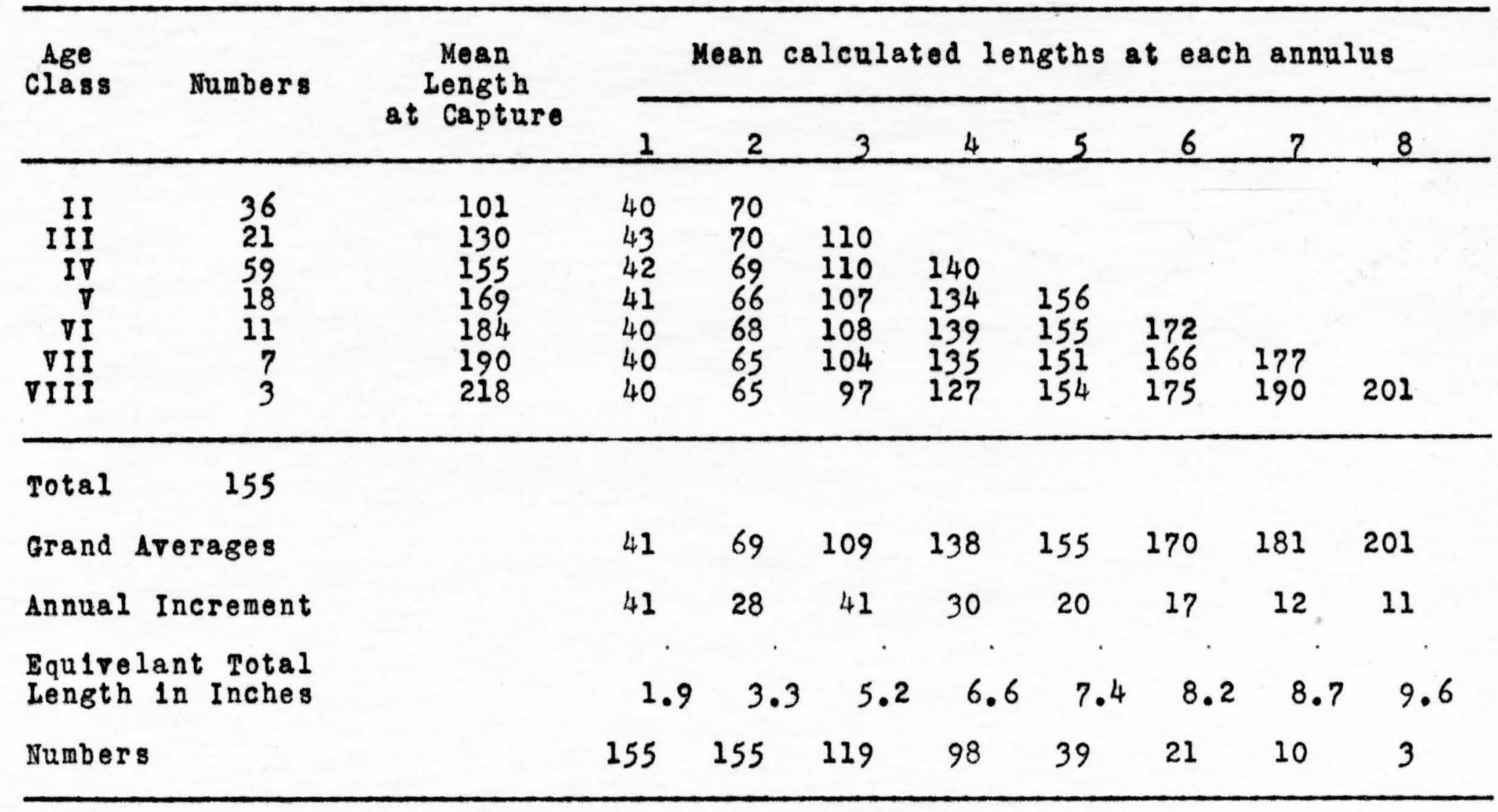


An interesting pattern in average annual increment is apparent in both populations. The increment between the flrst and second annuli is smaller than the increments for the first year of life and the third year of $11 \mathrm{fe}$. The calculated lengths for all age classes are consistent with the average. Clark (1953) finds a similar annual Increment pattern in Utah chub from Bear Lake, Idaho-Utah. S1gler (1948), from a small sample of Utah chub collected from a Cache Valley, Utah pond, also shows the growth increment to follow a similar pattern. A possible explanation of this pattern is one of differential food ava1lability. 
BVALUATION OF THE METHODS AND CONCLUSIONS

The opercular bone method shows no great differences from the scale method in final results. Slight differences do, however, show themselves in the presentation of the comparative data.

The techniques used for the preparation of the scales for analysis differs from the opercular bones in that the opercular bones need only be cleaned. The scales must be cleaned and mounted in suitable media on slides. Also, the scales must be projected or magnified to a degree where expensive optical equipment is necessary. The opercular bones are simply read and measured directly, alded only by a hand lens.

On the other hand, the opercular bone requires additional measurements for curvature correction not necessary for the scales. The operation for the correction of curvature is involved and increases chance for error, consequently detracting from the efficiency of the opercular bone method.

The body length-scale radius and the body lengthopercular bone radius relationshlps are essentially similar. The body-opercular bone relationsh1p is slightly curvi11near. The curvilinearity, in practice, actually affects only those flsh below $20 \mathrm{~mm}$. In standard length. The 
remainder of the regression line is essentially linear. This is compared to the almost complete linearity of the body-scale relationship.

The variance of the growth calculations appears to increase with the age of the fish by the scale method, whlle the variance appears to remain more constant by the opercular bone method. Subsequently, it would appear that growth determined by opercular bones is more accurate for the older age classes, while the growth determined by the scales is more accurate for the younger age classes. These varlances are, however, apparently based on a normal distribution, since the average calculated lengths show little difference by the two methods.

With the evidence presented, the opercular bone method for age and growth determination of the Utah chub shows no appreciable advantages over the scale method. 


\section{LITERATURE CITED}

Carlander, Kenneth $D$.

1950 Handbook of freshwater f1shery b10logy. Wm. C. Brown Co. Dubuque, Iowa. $281 \mathrm{pp}$.

Clark, William J.

1953

A Iife history of the Utah chub, Gila atraria atrarla (Girard), from the literature and from collections taken in Bear Lake, Utah-Idaho. U. S. A. C. Logan, Utah. Unpublished manuscript.

Creaser Charles W.

1926 The structure and growth of the scales of fishes in relation to the interpretation of their life history, with special reference to the sunfish Eupomotis glbbosus. Mus. of Zool. U. of Mich. Misc. Publ. Mo. 17. $82 \mathrm{pp}$.

Fenneman, Nevin $M$.

1931 Physlography of Western United States. McGray-H111 Book Co. N. Y. 534 pp.

Hazzard, A. S.

1935 A prellminary study of an exceptionally productive trout water, Fish Lake, Jtah. Trans. Am. Fish. Soc. Vol. 65 (1934). pp.222-228.

H1le, Ralph

1941

Age and growth of the rock bass Ambloplites rupestr1s Rafin1sque in Nebish Lake, WisConsin. Trans. W1s. Acad. Sc1., Arts, and Lett. Vol. 33. pp. 189-337.

Jordan David Starr

1891 Report of explorations in Colorado and Utah In 1889, with an account of the fishes found in each of the river basins examined. Bull.

U. S. Fish Comm. Vol. 9 (1889). $40 \mathrm{pp}$.

Lagler, Karl $r$.

1950 Studies in freshwater P1shery biology. J. W. Edwards. Ann Arbor, Mich. 207 pp. 
LeCren, E. D.

1947 The determination of the age and growth of

the perch (Perca fluviat1lis) from the

opercular bone. Jour. Animal Ecol. Vol.

16. \$o. 2. pp. 188-204.

MeConnell, William J.

1952 The opercular bone as an indicator of age

and growth of the carp cyprinus carpio

Linnaeus. Trans. Am. F1sh. Soc. V01. 81

(1951). pp. 138-149.

McKee, Edwin D.

Anclent landscapes of the Grand Canyon

region. Coconino Sun Co. Flagstaff, Ariz. $51 \mathrm{pp}$.

Sigler, W11liam $\mathrm{F}$.

1948 Pond studies. Utah State Cooperative WildIife Research Unit Quarterly Report. Logan, Utah. Vol. 13. No. 1. pp. 40-45.

\footnotetext{
1953 The collection and interpretation of life history data. William F. Sigler and Wildife Management Department, U. S. A. C. Logan, Utah. $46 \mathrm{pp}$.
}

Van Oosten, John

1929 Life history of the lake herring Leucichthys arted 1 LeSueur of Lake Huron as revealed by its scales, with a critique of the scale method. Bull. U. S. Bur. Fish. Vol. 44. pp. $265-428$. 